\title{
ПІДГОТОВКА КАДРІВ ЯК ІНСТРУМЕНТ УПРАВЛІННЯ СУСПІЛЬНИМИ ВІДНОСИНАМИ: АДАПТИВНИЙ ПІДХІД В КОНТЕКСТІ ПРОБЛЕМАТИКИ ДЕМЕНЦЇ̈
}

$\boldsymbol{X у д о б а ~ O . B . , ~ к а н д . ~ н а у к ~} з$ держ. упр., Львівський регіональний інститут державного управління Національної академії державного управління при Президентові України, м. Львів, Україна

Автор статті акиентує увагу на тому, що соціальні перетворення, обумовлені зміною демографічної структури населення, потребують удосконалення державно-управлінських підходів до формування нової медико-сочіальної стратегії. Кількість людей з деменцією у всьому світі збільшується з кожним роком у міру того, як старіє населення і уряд нашої краӥни повинен звернути більше уваги на формування державної політики у иььому аспекті. Успіх перетворень значною мірою буде залежати, з одного боку, від розуміння та усвідомлення проблематики демениії державними службовцями, які формують політику, а з іншого - від готовності до иүих змін суб 'єктів, які безпосередньо ї̈ реалізують.

Мета нашої статті полягає в актуалізації потреби підготовки медичних кадрів для вирішення питань деменції як медико-сочіальної проблеми в Україні, розкритті тенденцій ї̈ розвитку та змісту, а також окресленні напрямів удосконалення державного управління у иььому напрямі завдяки використанню адаптивного підходу до підготовки кадрів, щуо сприятиме підвищенню ефективності діяльності галузі охорони здоров'я загалом, здійснення ї̈ на засадах компетентності та професіоналізму.

Освіта лікарів і медичних сестер розглядається в статті не з суто теоретичної точки зору, а з позичї компетентнісного підходу, шьо зумовлено спрямуванням на їх практичну діяльність.

Встановлено, щуо кваліфікація медичних кадрів з питань деменції, особливо сімейних лікарів, невропатологів, психіатрів та медич- 
них сестер в Україні на сьогодні є низькою. Це призводить до низького рівня обізнаності населення про деменцію як захворювання; унеможливлення визначення потреб у послугах на різних стадіях захворювання, а також обсягах ичих послуг; низького рівня пріоритетності демениії як медико-соціальної проблеми в суспільстві.

Одним з інструментів державного управління щзодо підвищення професійної компетентності, спричинених зовнішніми чинниками, може бути використання адаптивного підходу. Цей підхід до підготовки кадрів має забезпечувальний характер і грунтується на потребах у пристосуванні до соціальних умов, щуо склалися в умовах сьогодення. Встановлено, щуо в умовах сьогодення адаптивний підхід може бути реалізований через програму безперервного професійного навчання.

Ключові слова: державне управління; політика охорони здоров'я; деменція; підготовка медичних кадрів; адаптивний підхід.

Постановка проблеми у загальному вигляді. Кількість людей $з$ деменцією у всьому світі збільшується з кожним роком у міру того, як старіє населення. Деменція є наслідком різних захворювань та травм, які первинно або вторинно вражають головний мозок. До таких захворювань відноситься, наприклад, хвороба Альцгеймера - найпоширеніша форма деменції, що складає до 60-70 \% усіх випадків деменції, або наслідки інсульту. Хоча деменція вражає переважно людей похилого віку, це не є нормою старіння, як часто вважається. Це захворювання є одним з головних причин залежності хворих від сторонньої допомоги серед людей похилого віку в усьому світі і має фізичний, психологічний, соціальний та економічний вплив на їх опікунів, сім'ї та суспільство загалом, чим створює значне зниження якості їхнього життя. Тому Всесвітня організація охорони здоров'я визнає деменцію як пріоритетне питання охорони здоров'я XXI століття і закликає уряди країн звернути більше уваги на формування державної політики у цьому аспекті [1] з метою розвитку інтегрованої системи медико-соціальних послуг і збереження якості життя хворих на деменцію і осіб, що їх доглядають. 
Успіх таких перетворень значною мірою буде залежати, 3 одного боку, від розуміння та усвідомлення проблематики деменції державними службовцями, які формують політику, а з іншого - від готовності до цих змін суб'єктів, які безпосередньо ії реалізують. Специфіка розвитку цього захворювання і формування державних програм підтримки сімей, де є такі хворі, передбачає залучення фахівців різних галузей. Проте провідною ланкою фахівців, від якої залежить профілактика захворювання та його діагностика на ранньому етапі, підвищення загальної обізнаності суспільства про особливості перебігу деменції та догляду за такими хворим, залишаються медичні кадри, передовсім сімейні лікарі, невропатологи, психіатри та медичні сестри.

Стратегічною метою управління є підвищення ефективності діяльності галузі охорони здоров'я в цьому напрямі, здійснення ії на засадах компетентності та професіоналізму. Одним з інструментів державного управління щодо вирішення конкретних професійних завдань, спричинених зовнішніми чинниками, може бути використання адаптивного підходу. Цей підхід до підготовки кадрів має забезпечувальний характер і грунтується на потребах у пристосуванні до соціальних умов, що склалися в умовах сьогодення.

Саме тому важливим завданням держави на нинішньому етапі стає адаптація системи підготовки, перепідготовки та підвищення кваліфікації осіб відповідно до потреб суспільства, забезпечення високого рівня їх професійної компетентності, створення умов для їх безперервного розвитку і втілення функцій держави в контексті проблематики деменції.

Аналіз останніх досліджень і публікацій. У наукових джерелах існує низка публікацій, які присвячені дослідженню питань підготовки медичних кадрів, ролі ВНЗ у забезпеченні сталого розвитку держави і потреб суспільства, реформи системи охорони здоров'я тощо. Проте відсутнє системне дослідження участі навчальних закладів у підготовці фахівців для протидії зростаючій кількості вікозалежних захворювань, серед яких вагоме місце посідає деменція. На жаль, відчизняними науковцями ще не здійснювалося дослідження питань системи професійного навчання лікарів і медсестер в цьому напрямі. 
Незважаючи на активне дослідження вченими ролі ВНЗ у забезпеченні потреб суспільства, залишаються недостатньо вивченими питання підготовки фахівців для розв'язання проблем, обумовлених старінням населення.

Формулювання цілей статті (постановка завдання). Мета нашої статті полягає в актуалізації потреби підготовки медичних кадрів для вирішення питань деменції як медико-соціальної проблеми в Україні, розкритті тенденцій іiі розвитку та змісту, а також окресленні напрямів удосконалення державного управління у цьому напрямі завдяки використанню адаптивного підходу до підготовки кадрів, що сприятиме підвищенню ефективності діяльності галузі охорони здоров’я загалом, здійснення іiі на засадах компетентності та професіоналізму.

Актуалізація проблеми деменції в суспільстві залежить від показників поширеності цього захворювання і грунтується на його виявленні, особливо на ранніх етапах. Оскільки цей процес вимагає наявності необхідних знань і навиків у медичного персоналу, в межах дослідження ми поставили такі завдання:

- проаналізувати формування та підвищення професійної компетентності медичних кадрів як методу управління діяльністю системи охорони здоров'я;

- дослідити фактичний обсяг підготовки, що впливає на формування їх компетентностей з питань деменції;

- обгрунтувати підходи до підвищення професіоналізації медичних кадрів 3 питань деменції, використовуючи міжнародний досвід.

Виклад основного матеріалу. Передумовами до проведення детального аналізу за тематикою цього дослідження стали дві причини: 1) збільшення тривалості життя населення і зростання вікозалежних захворювань, що може стати додатковим навантаженням на систему охорони здоров'я в Україні та змушує уряд розробити механізми адаптації медичної галузі до цих викликів; 2) незважаючи на зростання поширеності деменції у всьому світі і розроблення національних чи регіональних програм багатьма країнами у відповідь, в Україні тематика деменції залишається поза увагою не лише державних управлінців та політиків, але й потребує активнішою 
участі медичної спільноти. Більше того, статистичні дані щодо поширеності деменції в Україні вказують на відсутність необхідності вживати невідкладних заходів, демонструючи позитивну динаміку, що не відповідає об'єктивності ситуації [2].

Дослідження та напрацювання державної політики в цій сфері необхідне саме тому, що Україна нині перебуває на стадії соціальних змін і відповідно потребує зміни державно-управлінських підходів. Подібні перетворення передбачають потребу у розроблені нової медико-соціальної стратегії і якісного її втілення, що неможливо без підвищення компетентностей безпосередніх її виконавців, передовсім лікарів і середнього медичного персоналу. Тому питання теорії підготовки та підвищення кваліфікації медичних кадрів, розвиток підходів, ідей та принципів їх професійного розвитку стає об'єктом державного управління.

Освіта лікарів і медичних сестер розглядається нами не з суто теоретичної точки зору, а з позиції компетентнісного підходу, що зумовлено спрямуванням на їх практичну діяльність. Такий підхід забезпечує професіоналізацію лікарів і максимальну ефективність ïx роботи, базуючись на знаннях, вміннях, навиках, здобутих шляхом освіти і підвищення кваліфікації.

Ухвалення Закону «Про вищу освіту» створило умови для посилення співпраці державних органів 3 закладами вищої освіти 3 метою підготовки конкурентоспроможного людського капіталу для інноваційного розвитку країни, забезпечення потреб суспільства, ринку праці та держави у кваліфікованих фахівцях [3]. Грунтуючись на принципах автономії закладів вищої освіти, це забезпечує можливість для закладів самостійно і незалежно приймати рішення стосовно розвитку академічних свобод, організації освітнього процесу, наукових досліджень тощо. Заклад вищої освіти може самостійно запроваджувати спеціалізації (ст. 9-1), які є складовою спеціальності, що визначається закладом вищої освіти та передбачає профільну спеціалізовану освітню програму підготовки здобувачів вищої та післядипломної освіти (ст. 1) [4].

Заклади вищої освіти мають рівні права, що становлять зміст їх автономії та самоврядування, у тому числі мають право (ст. 32) [5]: 
1) розробляти та реалізовувати освітні (наукові) програми в межах ліцензованої спеціальності;

2) самостійно визначати форми навчання та форми організації освітнього процесу;

3) обирати типи програм підготовки бакалаврів і магістрів, що передбачені Міжнародною стандартною класифікацією освіти.

Обов'язковими до виконання всіма закладами вищої освіти незалежно від форми власності та підпорядкування для кожного рівня вищої освіти в межах кожної спеціальності є:

- стандарт освітньої діяльності, тобто сукупність мінімальних вимог до кадрового, навчально-методичного, матеріально-технічного та інформаційного забезпечення освітнього процесу закладу вищої освіти, що розробляється та затверджується центральним органом виконавчої влади у сфері освіти і науки за погодженням з Національним агентством із забезпечення якості вищої освіти (ст. 9) [6].

- стандарт вищої освіти - сукупність вимог до змісту та результатів освітньої діяльності закладів вищої освіти і наукових установ за кожним рівнем вищої освіти в межах кожної спеціальності, що розробляються в межах кожної спеціальності відповідно до Національної рамки кваліфікацій і використовуються для визначення та оцінювання якості змісту та результатів освітньої діяльності закладів вищої освіти (ст. 10) [7].

Заклад вищої освіти на підставі відповідної освітньої програми за кожною спеціальністю розробляє навчальний план, який визначає перелік та обсяг навчальних дисциплін у кредитах СКТС, послідовність вивчення дисциплін, форми проведення навчальних занять та ïх обсяг, графік навчального процесу, форми поточного і підсумкового контролю. Результатом навчання на певному рівні вищої освіти $€$ отримання комбінації знань, вмінь і практичних навичок, способів мислення, професійних, світоглядних і громадянських якостей, морально-етичних цінностей, які визначають здатність особи успішно здійснювати професійну та подальшу навчальну діяльність, тобто визначають їі компетентність.

3 огляду на вищеозначене, нами проведено аналіз механізму формування компетентності лікарів, передовсім сімейних лікарів, 
3 питань деменції, оскільки саме вони безпосередньо залучені до діагностики захворювання на ранніх етапах. Такий аналіз проведено вперше серед вищих навчальних закладів шляхом формування запиту на отримання інформації, зважаючи на їх автономізацію. Вибір закладів відбувався за такими критеріями: 1) фахове спрямування закладів (підготовка лікарів чи медсестер); 2) етапність підготовки медичних кадрів (заклади, що здійснюють додипломну і післядипломну підготовку; 3) академічний рейтинг закладу [8], що представлений Центром міжнародних проектів «Євроосвіта» в партнерстві з міжнародною групою експертів IREG Observatory on Academic Ranking and Excellence,

В результаті комплексного підходу за означеними критеріями було відібрано десять ВНЗ додипломної підготовки лікарів, які увійшли до перших ста рейтингових позицій закладів України, та три ВНЗ післядипломної підготовки лікарів. Щодо підготовки медичних сестер запити надсилалися до ВН3, що функціонують у Львівській області, зокрема 5 закладів додипломної підготовки (4 медичні коледжі і медична академія) і медичного коледжу післядипломної підготовки.

Узагальнюючи отриману інформацію, можна стверджувати: кафедри загальної практики - сімейної медицини та внутрішніх хвороб вищих навчальних медичних закладів на додипломному етапі не викладають питання деменції для підготовки лікарів. Частково ця тематика розглядається при вивченні дисципліни «Психіатрія та наркологія»: лекційний матеріал здебільшого не передбачено навчальними планами, лише в середньому 4-6 год відводиться на практичні заняття та 10-16 год - на самостійне вивчення. Для підготовки медичних сестер у ВНЗ тематика деменції, як окрема тема, також не передбачається, але фрагментарно розглядається в окремих розділах навчальних дисциплін загальним обсягом 1-1,5 год. Таким чином, аналіз робочих програм, тематики аудиторних занять і самоосвіти, та кількість відведених на це годин дає нам підстави вважати, що на рівні додипломної підготовки ВНЗ в Україні не формують належної компетентності ні лікарів, ні медичних сестер 3 питань попередження, виявлення, діагностування та подальшого 
лікування деменції, медичного супроводу хворих деменцією та роботи з особами, які їх доглядають.

Коли уповноважена установа встановила, що особа досягла компетентностей (результатів навчання) відповідно до стандартів вищої освіти вона підлягає офіційному оцінюванню і визнанню результатів, що підтверджує отриманню відповідної кваліфікації.

Атестація здобувачів освітньо-кваліфікаційного рівня спеціаліст, ступеня вищої освіти магістр за спеціальностями галузі знань «22 Охорона здоров'я» здійснюється у формі єдиного державного кваліфікаційного іспиту, який складається з таких компонентів: інтегрований тестовий іспит «КРОК»; об'єктивний структурований практичний (клінічний) іспит; міжнародний іспит з основ медицини; іспит з англійської мови професійного спрямування; чи може проводитися в іншій формі, визначеній стандартом вищої освіти [9]. В галузі знань 22 - охорона здоров'я Міністерство освіти і наукиу2018-2019 рр. затвердило 6 стандартів (три - для першого (бакалаврського) рівня і три - для другого (магістерського) рівня) за спеціальностями: 221 - стоматологія [10]; 223 - медсестринство [11], 224 - технології медичної діагностики та лікування [12], [13], 227 - фізична терапія, ерготерапія [14], 229 - громадське здоров'я [15].

Іспит «КРОК»- стандартизований тест із фундаментальних та клінічних дисциплін, що перевіряє досягнення компетентностей здобувачів вищої освіти, визначених вимогами стандартів вищої освіти, розроблений державною організацією «Центр тестування професійної компетентності фахівців з вищою освітою напрямів підготовки “Медицина" i “Фармація” при Міністерстві охорони здоров’я України». Цей іспит проводиться в один або два тестових етапи - «КРОК 1» та «КРОК 2». На першому етапі оцінюється рівень професійної компетентності із загальнонаукових (фундаментальних) дисциплін, тоді як на другому - оцінюється рівень професійної компетентності із професійно орієнтованих (клінічних) дисциплін. Кваліфікаційний іспит проводиться в усіх закладах вищої освіти, які здійснюють підготовку фахівців за спеціальностями галузі знань «22 Охорона здоров'я». 
Аналізуючи бази тестів КРОК 2 із загальної лікарської підготовки, буклети яких доступні в режимі онлайн тестування або перегляду бази даних, встановлено, що серед 200 питань, що складали базу у 2018 р. [16], 15 питань стосувалося осіб старше 60 років, i жодного питання, де би згадувалася захворювання «деменція». Звідси ми знаходимо ще одне підтвердження гіпотези про недостатню компетенцію лікарів $з$ питань деменції: якщо оцінка теоретичного рівня професійної компетентності взагалі не передбачає питань 3 проблематики деменції, то ці питання в процесі додипломної підготовки лікарів розглядаються на рівні загальних уявлень.

На етапі підвищення рівня практичної підготовки випускників вищих медичних закладів освіти, що здійснюється через програми інтернатури, проблематика деменції розглядається за фахом «Психіатрія» та «Неврологія». Робочі програми інтернатури по психіатрії та неврології, що розраховані на два роки, передбачають в загальному 12 аудиторних годин.

Післядипломна освіта лікарів також має певні особливості обов'язкове навчання відбувається у чітко визначених Міністерством охорони здоров'я закладах - 3 державних академіях післядипломної освіти та 14 факультетах післядипломної освіти. Кількість годин, відведена на вивчення різних форм деменції, значно варіюється між закладами і зорієнтована лише на психіатрів і невропатологів. Сімейні лікарі на циклах підвищення кваліфікації вивчають означену тематику в межах 2 год.

Відсутність конкуренції на ринку освітніх послуг не стимулювала провайдерів освітніх послуг до осучаснення змісту навчальних програм [17], передбачала регламентований перелік видів навчання та не стимулювала лікарів вдосконалюватись [18]. Уряд України, шляхом затвердження Постанови КМУ від 28 березня 2018 р. № 302, прийняв рішення про зняття преференцій виключно державним провайдерам послуг з післядипломної медичної освіти і скасування обмеження переліку освітніх провайдерів для лікарів, таким чином демонополізувавши освітній ринок. Відтак започатковано новий підхід в освіті лікарів суть якого полягає у безперервному професійному розвитку та затверджено Положення про систему 
безперервного професійного розвитку фахівців у сфері охорони здоров'я [19].

Постановою передбачається створення агенції з питань безперервного професійного розвитку, яка контролюватиме якість роботи провайдерів освітніх послуг за чіткими параметрами, затвердженими MO3 України. Лікарі отримають доступ до переліку заходів таких перевірених провайдерів, а держава - інструмент контролю якості ринку професійного вдосконалення лікарів. Це, на думку урядовців, відкриває можливості для вільної конкуренції дозволить пристосовувати навчання до потреб конкретної медичної практики у конкретному лікувальному закладі і надасть безумовні переваги як для лікарів, так і для пацієнтів. Лікар сам матиме змогу обирати тематику та формати навчання, які він вважатиме за доцільне та необхідне відповідно до його індивідуальної потреби. Розширюються можливості навчатись дистанційно та стаціонарно, у державному чи приватному освітньому закладі як в Україні, так і за ії межами. За кожен вид навчання лікарю нараховуватиметься певна кількість балів, які підлягатимуть веденню обліку і працівником, і роботодавцем, та які обов'язково враховуватимуться під час атестації для присвоєння або підтвердження кваліфікаційної категорії або кваліфікації працівника чи продовження дії ліцензії на провадження господарської діяльності з медичної практики.

На території України організаторами (провайдерами) заходів безперервного професійного розвитку, за які нараховуються бали, можуть бути МO3, структурні підрозділи з питань охорони здоров'я обласних, Київської та Севастопольської міських держадміністрацій, наукові установи та організації, заклади вищої освіти та заклади післядипломної освіти, професійні асоціації та спілки, організації роботодавців, громадські організації, міжнародні організації, їх представництва в Україні, міжнародні професійні асоціації, українські підприємства, інші установи та організації тощо. Вимоги до таких заходів безперервного професійного розвитку затверджуються МO3.

Фінансування безперервного професійного розвитку фахівців у сфері охорони здоров'я здійснюється за рахунок бюджетних коштів відповідно до Реєстру медичних працівників та Реєстру медичних 
спеціалістів, затверджених постановою Кабінету Міністрів України [20] з урахуванням принципу індивідуального виділення фіксованої суми коштів на безперервний професійний розвиток окремого лікаря, а також за рахунок коштів фізичних та/або юридичних осіб та інших не заборонених законодавством джерел фінансування. Однак змінюється принципи фінансування професійного розвитку лікарів. За новими правилами «гроші підуть за лікарями», тобто на ті освітні заходи, які цікавлять конкретних лікарів та покращують конкретну лікарську практику.

В умовах демографічних змін, що пов'язано із збільшенням тривалості життя і поширення вікозалежних захворювань, таких як деменція, потребує адаптації система підготовки та підвищення кваліфікації лікарів, що, з нашого погляду, стає можливим власне через впровадження нової державної політики у сфері професійного навчання лікарів. Неможливо повністю врахувати індивідуальні потреби лікарів як фахівців та змісту всіх завдань, які необхідні для роботи на певній посаді. Цю можливість якраз відкриває система безперервної професійної освіти. Щоб відповідати вимогам часу лікар повинен постійно вдосконалюватися й забезпечувати можливості для власного розвитку та підвищення професіоналізації медичної галузі в цілому.

Принцип безперервного навчання фахівців сфери охорони здоров'я давно є поширеною практикою в розвинутих країнах Європи, Америки та Азії, зокрема у Великій Британії, США, Польщі, Чехії, Швеції, Сінгапурі та інших. Для українських лікарів такий компонент почав діяти з 2019 року [21].

Детальний аналіз розглянутих вище освітніх підходів дає підгрунтя для формування механізму розширення знань, вмінь та навиків лікарів, тобто їх професійного розвитку, з питань деменції. Безперервний професійний розвиток включає участь у процесі формальної, неформальної та інформальної освіти у сфері охорони здоров'я і усі фахівці у сфері охорони здоров'я після здобуття вищої освіти у сфері охорони здоров'я та отримання кваліфікації після закінчення навчання в інтернатурі для подальшої атестації зобов'язані дотримуватися цих вимог. Оскільки тематика деменції є ще відносно новою для України, з нашого погляду, доцільно ввести 
обов'язковий курс з вивчення різних форм деменції і особливостей їх перебігу на циклах підвищення кваліфікації та тематичного удосконалення для сімейних лікарів, а також розширити цю тематику для підготовки профільних фахівців. Отримання базових знань про особливості перебігу деменції, як ми сподіваємося, сприятиме зростанню потреби у неформальній освіті лікарів за цим напрямом. Шляхом розширення переліку провайдерів освітніх послуг можна залучати професійні організації міжнародного рівня для здійснення діяльності з підвищення знань та вмінь $з$ питань деменції не лише лікарів, але й середнього медичного персоналу, що може завершуватися присудженням часткових освітніх кваліфікацій.

Набуття відповідних компетентностей з питань деменції лікарями первинної ланки дозволить посилити виявлення хворих на деменцію на ранніх етапах розвитку захворювання, забезпечити належну співпрацю між сімейними лікарями та вузькими спеціалістами для надання належної якості медичних послуг цій групі населення, а також створить умови для ведення моніторингу хворих на деменцію з різними стадіями захворювання. Відтак підвищення кваліфікації лікарів у цьому напрямі $є$ тією основою, на якій формується обгрунтоване визначення усіх інших потреб хворих на деменцію, осіб, що здійснюють догляд за ними та підвищать обізнаність та толерантність суспільства до цих хворих.

Старіння населення змінює суспільство у всіх відношеннях. В міру того, як змінюється структура населення, домінує частка дорослих і зростає кількість осіб похилого віку, невід'ємним $є$ те, що повинна змінюватися інфраструктура і підходи до медичного обслуговування населення. У зв'язку з тим, що деменція відноситься до прогресуючих і невиліковних захворювань, виявлення захворюванням на ранньому етапі допоможе хворому і його сім’ї уникнути багатьох проблем та спланувати майбутній неминучий догляд. Тому наявність лікарів, що володіють необхідними навиками для цього, $€$ запорукою зниження навантаження на систему охорони здоров'я через зменшення необгрунтованих ушпиталень цих хворих і сприяння розвитку інфраструктури соціальних служб для покращення якості життя хворих й доглядальників. 
Хоча лікарі відіграють надзвичайно важливу роль у вирішенні медичних питань для хворих на деменцію, починаючи від діагностики захворювання і закінчуючи хоспісною допомогою, не менш важливою є підготовка середнього медичного персоналу і розвиток закладів сестринського догляду. На жаль, в Україні така підготовка поки що не здійснюється.

Актуальність запозичення міжнародного досвіду полягає в тому, що зміни системи управління будуть ефективними лише за умови значного підвищення рівня професіоналізму. Це передбачає удосконалення системи підготовки, перепідготовки та підвищення кваліфікації, що сприятиме професійному розвитку. У зв'язку з цим, доцільно звернутися до міжнародного досвіду у зазначеній сфері.

Інше розуміння і сприйняття деменції як медико-соціальної проблеми спостерігається в розвинутих країнах, наприклад, в Австралії, де обговорення можливих шляхів допомоги хворим на цю недугу і їх доглядальникам розпочалося більше тридцяти років назад. Маючи розвинуту мережу підготовки фахівців медичної галузі 3 питань деменції і об'єктивну потребу у послугах, Австралія активно розвиває конкуренцію між навчальними закладами і професійними організаціями щодо підготовки фахівців різних галузей з питань деменції, основою якої є міжсекторальний підхід.

До прикладу, на базі Тасманського університету утворено дослідницький і освітній центр 3 питань деменції (The Wicking Dementia Research and Education Centre) [22]. Діяльність цього інтегрованого центру спрямована на вивчення різних дисциплін, прагнучи покращити життя людей $з$ деменцією та їх опікунів. Проекти реалізуються і на національному, і на місцевому рівнях в таких галузях досліджень, як неврологія, медицина, сестринська справа, психологія, соціологія, здоров'я, економіка та політика. Центр має на меті:

- краще зрозуміти хвороби, що вражають мозок, які спричиняють прогресивне зниження функціонування організму, що впливає на пам'ять, навички та соціальну поведінку;

- розробити на основі доказів моделі надання допомоги людям 3 деменцією та особам, які їх доглядають; 
- вивчити траєкторію розвитку мозку та функціональні зміни старіння обумовлені деменцією;

- забезпечити освітні програми для формування знань та розуміння деменції в громаді.

Центр пропонує масовий відкритий онлайн-курс (Massive Open Online Course) [23] під назвою «Розуміння деменції», який забезпечує якісну університетську освіту про новітні наукові дослідження та догляд хворими з деменцією. Цей безкоштовний курс дає можливість ознайомитися з міжнародними досягненнями в цьому напрямі і не передбачає здачі іспитів. Маючи різні модулі, курс призначений для того, щоб бути доступним та цікавим для різної аудиторії, включаючи:

- медичні працівники;

- персонал спеціалізованих закладів чи закладів соціального захисту;

- людей на ранніх стадіях захворювання, їх родини та доглядальників;

- соціологів;

- соціальних працівників;

- політиків та керівників установ;

- осіб, що мають загальний інтерес до деменції.

Щоб отримати максимальну користь від цього курсу, учасники повинні приблизно витрачати 3 години на тиждень, займаючись змістом та виконуючи відповідні заняття з курсу. Запланований курс на 7 тижнів. Після завершення учасники отримують сертифікат про закінчення.

Університет пропонує також освітні програми з догляду за хворими 3 деменцією з отриманням диплому. Програми спрямовані на підготовку бакалаврів, спеціалістів та магістрів 3 питань деменції [24], а також є програми для підготовки докторів філософії за таким напрямом [25]. Післядипломний професійний розвиток спрямований на випускників та фахівців, які вже працюють або розвивають свій досвід в інституціях, де надаються послуги для хворих на деменцію. Курси пропонують всебічне розуміння деменції $з$ точки зору людей, сімей, громад, систем охорони здоров'я та урядів, а та- 
кож висвітлюють суто медичні питання, що стосуються нейробіології, патології, біомаркерів та терапевтичних засобів.

Альтернативне навчання можна пройти в інших центрах, які $\epsilon$ офіційними постачальниками освітніх послуг з питань деменції, зокрема Центрі, створеному професійним товариством «Альцгеймер Австралія», який надає комплексний набір послуг 3 навчання та консультування на основі доказів, які допомагають покращити якість життя людей, які живуть 3 деменцією [26].

Використовуючи результати сучасних наукових досліджень та практики, комплексний набір освітніх програм включає як акредитовані, так і неакредитовані курси, що проводяться віч-на-віч по всій Австралії, а також в мережі Інтернет. Команда фасилітаторів складається з висококваліфікованих фахівців, які мають досвід в галузі охорони здоров'я, освіти та роботи в громаді, та мають безпосередній досвід надання підтримки людям з деменцією та їх сім’ям. Усі фасилітатори мають необхідну кваліфікацію з навчання та оцінювання на робочому місці, мають диплом і кваліфікацію вищого рівня у навчанні дорослих. Сучасні галузеві навички фасилітаторів дозволяють їм створювати позитивний та необхідний досвід навчання. Вони мають постійну співпрацю з експертами та практиками 3 питань деменції, науковцями та здійснюють постійний професійний розвиток.

\section{Висновки 3 даного дослідження:}

Управлінський вплив на суспільні відносини охоплює всі без винятку сфери життя та здійснюється на всіх рівнях. Соціальні зміни, обумовлені зміною демографічної структури населення, потребують удосконалення державно-управлінських підходів у розроблені нової медико-соціальної стратегії. Якісне втілення нових перетворень неможливо без належної фахової підготовки безпосередніх іiі виконавців, передовсім лікарів та медичних сестер.

На основі аналізу робочих програм ВНЗ на етапах додипломної та післядипломної підготовки лікарів і медичних сестер встановлено, що кваліфікація медичних кадрів 3 питань деменції, особливо сімейних лікарів, невропатологів, психіатрів та медичних сестер в Україні на сьогодні є доволі низькою. Це призводить до: 
- низького рівня обізнаності населення про деменцію як захворювання у найпоширеніших іiі формах;

- фактичної відсутності можливості діагностики деменції на ранніх стадіях;

- унеможливлення визначення потреб у послугах на різних стадіях захворювання, а також обсягах цих послуг;

- низького рівня пріоритетності деменції як медико-соціальної проблеми в суспільстві.

Лише усвідомлення проблеми деменції в України дасть підстави до аналізу потреби у кваліфікованих кадрах з питань деменції, фахової підготовки лікарів і медичних сестер.

Періодичне галузеве підвищення кваліфікації та курсове навчання на даному етапі не задовольняють усіх потреб, які постають у процесі формування висококваліфікованого фахівця 3 належним рівнем професійної компетентності в Україні. Але використання можливостей автономізації вищих навчальних закладів і міжнародного досвіду може стати підгрунтям для впровадження адаптивного підходу до підготовки кадрів. 3 нашого погляду, найбільш дієвим підходом, за допомогою якого медична галузь зможе адаптуватися до потреб суспільства, $є$ розвиток безперервного професійного розвитку з питань деменції.

\section{Стаття надійшла до редакції: 15.07.19}

\section{STAFF TRAINING AS A TOOL FOR MANAGING SOCIAL RELATIONS: ADAPTIVE APPROACH IN THE CONTEXT OF THE DEMENTIA PROBLEM}

Oleksandra Khudoba, $\mathrm{PhD}$ in Public Administration, postdoctoral student, Lviv Regional Institute for Public Administration of the National Academy for Public Administration under the President of Ukraine, Ukraine

The author of the article emphasizes that social transformations caused by the changes in the demographic structure of the population require improvement of the state administrative approaches to the 
formation of a new medical and social strategy. The number of people living with dementia worldwide has been increasing every year since the ageing of population continue to grow. Hence the government of our country should pay more attention to making of public policy in this regard. The success of the transformation will largely depend, on the one hand, on the understanding and awareness of the dementia problem by policy-makers and, on the other hand, - on the readiness for these changes of the entities that directly implement it.

The purpose of our article is to actualize the need for medical training to address dementia as a medical and social problem in Ukraine, to identify trends in its development and content, as well as to outline directions for improving public administration in this area through the use of an adaptive training approach that will enhance the effectiveness of the health care industry in general, implementation of activities on the basis of competence and professionalism.

The education of doctors and nurses is considered in the article not only from a purely theoretical point of view, but from the competent approach's point of view, which is conditioned by the orientation to their practical activity.

It is established that the qualifications of medical staff in dementia issues, especially family doctors, neuropathologists, psychiatrists and nurses are low enough in Ukraine. This leads to low levels of public awareness of dementia as a disease; impossibility to determine the needs for services at different stages of the disease, as well as the scope of these services; low priority of dementia as a medical and social problem in society.

One of the tools of public administration to increase professional competence, caused by external factors, may be using of an adaptive approach. This approach to training has a supportive nature and is based on the need to adapt to the current social conditions. It is established nowadays that an adaptive approach can be implemented through a continuing vocational training program.

Keywords: public administration, health policy, dementia, medical training, adaptive approach.

\section{Received: 15.07 .19}




\section{References}

1. World Health Organization (2019). Dementia. https://www.who.int/ news-room/fact-sheets/detail/dementia [in English]

2. Khudoba O. Dementsiia: empirychna obgruntovanist derzhavnoi polityky v Ukraini [Dementia: the empirical rationale behind the Public Policy in Ukraine]: Monohrafiia. Lviv LA "Piramida", 2019. 428 s. [in Ukrainian]

3. Pro vyshchu osvitu [Elektronnyy resurs]: Zakon Ukrainy vid 1 lypnia 2014 roku No. 1556-VII. Retrieved from: https://zakon.rada.gov.ua/laws/ show/1556-18 [in Ukrainian]

4. ibid.

5. ibid.

6. ibid.

7. ibid.

8. Reitynh unyversytetov «TOP-200 Ukrayna» 2019 hoda Retrieved from:http://ru.osvita.ua/vnz/rating/64884/ [in Russian]

9. Pro zatverdzhennia Poriadku zdiisnennia yedynoho derzhavnoho kvalifikatsiinoho ispytu dlia zdobuvachiv stupenia vyshchoi osvity mahistr za spetsialnostiamy haluzi znan "22 Okhorona zdorov'ia” [Elektronnyy resurs]: Postanova Kabinetu Ministriv Ukrainy vid 28 bereznia 2018 r. No. 334. Retrieved from: https://zakon.rada.gov.ua/laws/show/334-2018-\%D0\%BF [in Ukrainian]

10. Pro zatverdzhennia standartu vyshchoi osvity za spetsialnistiu 221 "Stomatolohiia" dlia druhoho (mahisterskoho) rivnia vyshchoi osvity [Elektronnyy resurs]: Nakaz Ministerstva osvity i nauky Ukrainy vid 24.06.2019 r. No. 879. Retrieved from: https://mon.gov.ua/storage/app/media/vishchaosvita/zatverdzeni\%20standarty/2019/06/25/221-stomatologiya-magistr.pdf [in Ukrainian]

11. Pro zatverdzhennia standartu vyshchoi osvity za spetsialnistiu 223 "Medsestrynstvo" dlia pershoho (bakalavrskoho) rivnia vyshchoi osvity [Elektronnyy resurs]: Nakaz Ministerstva osvity i nauky Ukrainy vid 05.12.2018 r. No. 1344. Retrieved from: https://mon.gov.ua/storage/app/media/vishchaosvita/zatverdzeni\%20standarty/12/21/223-medsestrinstvo-bakalavr.pdf [in Ukrainian]

12. Pro zatverdzhennia standartu vyshchoi osvity za spetsialnistiu 224 "Tekhnolohii medychnoi diahnostyky ta likuvannia" dlia pershoho (bakalavrskoho) rivnia vyshchoi osvity [Elektronnyy resurs]:Nakaz Ministerstva osvity i nauky Ukrainy vid 19.12.2018 r. No. 1420. Retrieved from:https://mon. 
gov.ua/storage/app/media/vishcha-osvita/zatverdzeni\%20standarty/12/21/224tekhnologii-medichnoi-diagnostiki-ta-likuvannya-bakalavr.pdf [in Ukrainian]

13. Pro zatverdzhennia standartu vyshchoi osvity za spetsialnistiu 224 "Tekhnolohii medychnoi diahnostyky ta likuvannia" dlia druhoho (mahisterskoho) rivnia vyshchoi osvity [Elektronnyy resurs]: Nakaz Ministerstva osvity i nauky Ukrainy vid 25.06.2019 r. No. 884 Retrieved from: https://mon.gov. ua/storage/app/media/vishcha-osvita/zatverdzeni\%20standarty/2019/06/25/224tekhnologii-medichnoi-diagnostiki-ta-likuvannya-magistr.pdf [in Ukrainian]

14. Pro zatverdzhennia standartu vyshchoi osvity za spetsialnistiu 227 "Fizychna terapiia, erhoterapiia" dlia pershoho (bakalavrskoho rivnia vyshchoi osvity [Elektronnyy resurs]: Nakaz Ministerstva osvity i nauky Ukrainy vid 19.12.2018 r. No. 1419. Retrieved from: https://mon.gov.ua/storage/app/media/ vishcha-osvita/zatverdzeni\%20standarty/2019/05/08/227-fizichna-terapiyaergoterapiya-bakalavr.pdf [in Ukrainian]

15. Pro zatverdzhennia standartu vyshchoi osvity za spetsialnistiu 229 "Hromadske zdorov'ia" dlia druhoho (mahisterskoho) rivnia vyshchoi osvity [Elektronnyy resurs]: Nakaz Ministerstva osvity i nauky Ukrainy vid 12.12.2018 r. No. 1383. Retrieved from: https://mon.gov.ua/storage/app/media/vishchaosvita/zatverdzeni\%20standarty/12/21/229-gromadske-zdorovya-magistr.pdf [in Ukrainian]

16. Buklet 2018 roku. Retrieved from: https://xn--80adi8aaufcj8j.xn-$\mathrm{j} 1 \mathrm{amh} / \mathrm{testkrok} /$ base/772 [in Ukrainian]

17. Bezperervnyi profesiinyi rozvytok. Retrieved from: https://moz.gov. ua/bezperervnij-profesijnij-rozvitok [in Ukrainian]

18. MOZ Ukrainy opryliudnylo dlia hromadskoho obhovorennia nakaz pro bezperervnyi profesiinyi rozvytok likariv. Retrieved from: https://moz.gov. ua/article/news/moz-ukraini-opriljudnilo-dlja-gromadskogo-obgovorennjanakaz-pro-bezperervnij-profesijnij-rozvitok-likariv

19. Deiaki pytannia bezperervnoho profesiinoho rozvytku likariv [Elektronnyy resurs]: Nakaz Ministerstva okhorony zdorovia vid 22.02.2019 roku No. 446. Retrieved from: https://moz.gov.ua/article/ministry-mandates/ nakaz-moz-ukraini-vid-22022019--446-dejaki-pitannja-bezperervnogoprofesijnogo-rozvitku-likariv [in Ukrainian]

20. Deiaki pytannia elektronnoi systemy okhorony zdorov'ia [Elektronnyy resurs]: Postanova Kabinetu Ministriv Ukrainy vid 25 kvitnia 2018 r. No. 411. Retrieved from: https://zakon.rada.gov.ua/laws/show/411-2018-p [in Ukrainian]

21. Bezperervnyi profesiinyi rozvytok. Retrieved from: https://moz.gov. ua/bezperervnij-profesijnij-rozvitok [in Ukrainian] 
22. About Wicking Dementia Centre. Retrieved from: https://www.utas. edu.au/wicking/about [in English]

23. Understanding Dementia MOOC Retrieved from: https://www.utas. edu.au/wicking/understanding-dementia [in English]

24. Bachelor of Dementia Care Retrieved from: http://www.utas.edu.au/ wicking/bdc [in English]

25. Postgraduate study in Dementia Retrieved from: http://www.utas.edu. $\mathrm{au} /$ wicking/mdem [in English]

26. Centre for Dementia Learning Retrieved from: http://dementialearning. org.au/about-us/ [in English]

\section{Відомості про автора / Information about the Authors}

Худоба Олександра Василівна: Львівський регіональний інститут державного управління Національної академії державного управління при Президентові України. вул. Сухомлинського, 16, м. Львів-Брюховичі, 79491, Україна.

Oleksandra Khudoba: The Lviv regional institute of public administration, the National Academy for Public Administration under the President of Ukraine. Bruchovichi str. Lviv, 79491, Ukraine.

ORCID. ORG./ 0000-0001-6944-2163

E-mail: khudoba_o@academy.lviv.ua 